\title{
ANALIZA OBOWIĄZUJĄCYCH W POLSKIM PRAWIE KARNYM UNORMOWAŃ DOTYCZĄCYCH PROCEDERU HANDLU DZIEĆMI
}

Handel dziećmi, zawierający się w szeroko pojętym handlu ludźmi, jest zjawiskiem nasilającym się w szybkim tempie, a jego skala ze względu na wiele problemów, m.in. związanych z identyfikacją ofiar, jest trudna do oszacowania ${ }^{1}$. Świadomość tego faktu towarzyszy bez wattpienia podejmowanym wysiłkom na płaszczyźnie międzynarodowej dążącym do ulepszenia narzędzi prawa i udoskonalenia praktycznej współpracy w zakresie zwalczania tego procederu. W związku z powyższym niezbędne jest jego ciągłe monitorowanie, by weryfikować adekwatność uregulowań prawnych do zmieniającej się rzeczywistości, a przede wszystkim zapewnić maksymalną ochronę dzieciom. Handel dziećmi jako samodzielne zjawisko nie funkcjonuje w świadomości społecznej ${ }^{2}$. Nie stanowi on również przedmiotu odrębnej regulacji w Kodeksie karnym. Handel dziećmi był często utożsamiany $\mathrm{z}$,nielegalną adopcja”, określaną też jako adopcja „dzika” lub „podziemna”, która rozumiana jest jako niezgodna z przepisami ustawy forma przysposobienia niepodlegająca kontroli zewnętrz$n^{3}{ }^{3}$. Jednakże w wyniku wprowadzonej w 2010 r. nowelizacji Kodeksu karnego wyraźnie odróżniono przestępstwo handlu ludźmi (art. 189a k.k.) od przestępstwa organizowania adopcji wbrew przepisom ustawy (art. 211a k.k.). I choć ochrona dziecka, co nie ulega wątpliwości, zawiera się w znamionach przestępstwa handlu ludźmi z art. 189 a k.k., to jednak warto rozważyć, czy zjawisko handlu dziećmi winno zostać unormowane w sposób odrębny, szczególnie w płaszczyźnie kary, a co za tym idzie, czy ustawodawca winien zmienić obowiązujące w tym zakresie unormowania.

Jednym z podstawowych przymiotów przemawiających za wyróżnieniem specjalnej ochrony dziecka przed przestępstwem handlu dziećmi jest jego bezbronność wobec tego procederu ${ }^{4}$, który w głównej mierze opiera się na

${ }^{1}$ D. Gajewska, G. Kuhn, A. Popławska, Problem handlu dziećmi $w$ Polsce $i$ na świecie. Charakterystyka zjawiska i regulacje prawne, Fundacja Dzieci Niczyje, Warszawa 2012, s. 3.

${ }^{2}$ A. Morawska, Handel dziećmi-zarys zjawiska, w: Z. Lasocik (red.), Handel ludźmi-zapobieganie i ściganie, Warszawa 2006, s. 304.

${ }^{3}$ M. Pomarańska-Bielecka, Komercyjna adopcja dzieci, w: Z. Lasocik, M. Koss, Ł. Wieczorek (red.), Handel dziećmi - wybrane problemy, Warszawa 2007, s. 43.

${ }^{4}$ M. Kukułowicz, Polityka Unii Europejskiej wobec problemu handlu dziećmi, www.dziecko krzywdzone,pl, s. 2 (dostęp: 10.11.2012). 
oszustwie i manipulacji ${ }^{5}$. Współcześnie handel dziećmi przybiera bowiem dość zawoalowane formy, często zupełnie inne niż przy najbardziej powszechnym handlu kobietami do prostytucji. Dzieci będące ofiarami handlu sa zmuszane m.in. do przemytu i popełniania innych przestępstw, żebractwa, pracy niewolniczej, usług seksualnych i produkcji materiałów pornograficznych, a także nielegalnie adoptowane ${ }^{6}$. Ponadto dzieci nierzadko sa ,,wynajmowane" do pracy przymusowej lub padają ofiarą handlu narządami. Często takie zjawiska są błędnie kojarzone $\mathrm{z}$ demoralizacja nieletniego czy forma zaniedbywania przez rodziców, podczas gdy konieczne jest zrozumienie istoty i złożoności tego problemu, a w szczególności jego zorganizowanego charakteru. Powierzchowne traktowanie omawianego zjawiska powoduje, że takie sprawy (jeśli w ogóle zostaną wykryte) kończą się w sądzie rodzinnym, natomiast osoby czerpiące zysk z eksploatacji nieletniego często nie ponoszą żadnej odpowiedzialności ${ }^{7}$.

Ze względu na wysoki stopień społecznej szkodliwości tego typu praktyk należałoby postulować wprowadzenie odrębnej penalizacji handlu dziećmi. Dlatego też de lege ferenda należy wnioskować o zmianę przepisów w zakresie handlu ludźmi statuujących kwalifikowany typ przestępstwa handlu dziećmi i wydzielenie z przestępstwa handlu ludźmi odrębnej, kwalifikowanej regulacji dotyczącej handlu dziećmi. W legislacyjnej tradycji prawa polskiego dominuje bowiem koncepcja bezwzględnej ochrony dziecka, wynikająca zarówno z prawa krajowego, jak i międzynarodowego. Należytą zaś ochronę interesów dziecka zapewni bez watpienia wprowadzenie wskazanych zmian. Kryminologiczny obraz handlu ludźmi i handlu dziećmi pokazuje olbrzymią rożnorodność zachowań przestępczych - nielegalne pośrednictwo pracy, zastępcze rodzicielstwo, wspomniane wyżej przemyt, żebractwo, prostytucja, produkcja materiałów pornograficznych czy niewolnictwo. Niełatwo w Kodeksie karnym wskazać inny typ przestępstwa o tak zróżnicowanej postaci. Różnorodność ta dotyczy zarówno towarzyszącego sprawcy celu, jak i sposobu jego zachowania oraz sposobu wykorzystania ofiary ${ }^{8}$. Co prawda zarówno handel ludźmi, jak i handel dziećmi posiadaja wspólny wyznacznik, którym jest naruszenie godności ofiary i jej uprzedmiotowienie, należy jednak zwrócić uwagę, że handel ludźmi stanowi jednak większy zbiór obejmujący różnorodne postacie zachowań sprawcy. Wyodrębnienie z tego zbioru desygnatu handlu dziećmi przez stworzenie typu kwalifikowanego przestępstwa handlu dziećmi oraz zaostrzenie odpowiedzialności za naruszenie jego dóbr prawnie chronionych zapewni należytą ochronę dziecka. Ponadto można powiedzieć, że wskazana powyżej różnorodność zjawiska handlu ludźmi wręcz „domaga się” w tym wypadku kazuistyki i wyodrębnienia przestępstwa handlu dziećmi, choć co do zasady

\footnotetext{
5 A. Morawska, op. cit., s. 309.

${ }^{6}$ Ibidem, s. 304.

${ }^{7}$ M. Pomarańska-Bielecka, M. Wiśniewski, Analiza przepisów prawa dotyczacych zapobiegania i przeciwdziatania zjawisku handlu dziećmi, Warszawa 2010, s. 5.

${ }^{8}$ O. Sitarz, Watpliwości i kontrowersje wokót definicji handlu ludźmi, ,Archiwum Kryminologii” 32, 2010 , s. 331.
} 
w prawie karnym aprobującym ujęcie syntetyczne przepisów karnych jest ona niepożądana. O potrzebie utworzenia kwalifikowanego typu przestępstwa handlu dziećmi świadczy kryminologiczny obraz tego zjawiska.

Karnoprawna ochrona dziecka winna być traktowana przez ustawodawce w sposób priorytetowy, skoro sama ustawa zasadnicza - Konstytucja $\mathrm{RP}^{9}$ w art. 72 ust. 1 zapewnia ochronę praw dziecka oraz gwarantuje każdemu prawo żądania od organów władzy publicznej ochrony dziecka przed przemoca, okrucieństwem, wyzyskiem i demoralizacją. W ust. 2 cyt. przepisu ustawodawca wskazał, iż Konstytucja zapewnia, że każde dziecko pozbawione opieki rodzicielskiej ma prawo do opieki i pomocy władz publicznych. Powyższe gwarancje konstytucyjne odnoszą się do każdego dziecka, bez względu na jego narodowość, a więc Konstytucja RP zapewnia również ochronę praw dzieci cudzoziemskich $^{10}$.

Tymczasem pomimo traktowania dziecka na szczególnych prawach brak w obecnym Kodeksie karnym decyzji legislacyjnych, które zaostrzałyby odpowiedzialność sprawcy za proceder handlu dziećmi. Co więcej, Kodeks karny nie normuje definicji dziecka, a co za tym idzie - również i definicji handlu dziećmi. Zawarta w art. $115 \S 22$ definicja handlu ludźmi również nie odnosi się dosłownie do dziecka, a jedynie do osoby małoletniej.

Ustawodawca w art. $115 \S 22$ k.k. nie mówi o człowieku, a o osobie i czyni to, zdaje się, w sposób celowy. Według słowników języka polskiego „osoba” rozumiana jest jako, ,jednostka ludzka, człowiek, postać” ${ }^{11}$. Zgodnie ze wskazanymi słownikami przez pojęcie człowieka należy rozumieć ,,istotę żywą [...] wyróżniająca się najwyższym stopniem rozwoju psychiki i życia społecznego, jedyną zdolną do tworzenia kultury" ${ }^{12}$, natomiast przez pojęcie dziecka „niedorosłą istotę ludzką od urodzenia do wieku młodzieńczego” ${ }^{13}$, czy też ,człowieka od urodzenia do wieku młodzieńczego" ${ }^{14}$. W takim rozumieniu nie pozostawia się wątpliwości, że status dziecka osiągnąć można dopiero po narodzeniu. Zastanowić jednak się warto, czy jest to założenie słuszne i czy taka definicja winna stosowana być także w odniesieniu do prawa karnego, gdy mówimy o zapewnieniu bądź próbie zapewnienia przez państwo pełnej ochrony dziecka przed przestępstwem handlu ludźmi.

Stąd też zasadniczy problem prawnokarnej ochrony dziecka wynika z braku wyraźnie określonego momentu, od jakiego zaczyna się jego prawna ochrona. Brak w polskim ustawodawstwie jednolitości co do samej definicji dziecka powoduje, że sporna staje się także regulacja przestępstwa handlu dziećmi. Sprowadzając rozważania do zagadnień stricte prawnych, należy zauważyć, że ani przepisy Kodeksu karnego, ani Kodeksu rodzinnego i opiekuńczego ${ }^{15}$, ani

\footnotetext{
${ }^{9}$ Konstytucja Rzeczypospolitej Polskiej z 2 kwietnia 1997 r., Dz. U. 1997, Nr 78, poz. 483 ze zm.

${ }^{10}$ M. Pomarańska-Bielecka, M. Wiśniewski, op. cit., s. 66.

${ }^{11}$ E. Sobol, Stownik języka polskiego, Warszawa 2005, s. 619; L. Drabik et al., Stownik języka polskiego, Warszawa 2006, s. 596.

12 E. Sobol, op. cit., s. 113.

13 Ibidem, s. 176.

14 L. Drabik et al., op. cit., s. 176.

15 Dz. U. 2012, Nr 0, poz. 788.
} 
też Kodeksu cywilnego ${ }^{16}$ nie definiuja bezpośrednio pojęcia dziecka ${ }^{17}$. Skoro górna granica wieku dziecka jest określona w stosunkowo przejrzysty sposób, to należałoby się zastanowić, od jakiego momentu mamy do czynienia z dzieckiem będącym przedmiotem ochrony. W polskich przepisach prawnych definicja dziecka występuje w ustawie z 6 stycznia 2000 r. o Rzeczniku Praw Dziecka ${ }^{18}$, zgodnie z którą dzieckiem jest każda istota ludzka od poczęcia do osiągnięcia pełnoletności (art. 2 ust. 1 ustawy). Powstaje więc istotne pytanie, czy w rozumieniu prawa karnego przedmiot handlu dziećmi może stanowić tylko narodzone dziecko czy też dziecko poczęte, które jeszcze się nie narodziło.

Oczywiste jest, że nie należy skonstruowanej na potrzeby powyższej ustawy definicji dziecka traktować jako właściwą dla całego systemu prawa. Jednakże trzeba mieć na względzie, że głównym celem działań podejmowanych przez rzecznika praw dziecka jest zapewnienie dziecku pełnego i harmonijnego rozwoju, z poszanowaniem jego godności i podmiotowości, które są również dobrem chronionym na gruncie przepisów k.k. ${ }^{19}$ J. Potulski wskazał, że przepisy k.k. co prawda nie bezpośrednio, ale definiują dziecko jako osobę od momentu poczęcia do chwili osiągnięcia pełnoletności. Autor ten zastrzegł jednocześnie, że powyższa definicja stanowi regułę o charakterze generalnym, odnosząca się wyłącznie do systemu polskiego prawa karnego i nie można jej przypisywać charakteru interdyscyplinarnego ${ }^{20}$. Tę najszerszą definicję dziecka należy stosować, jeżeli ze względu na dodatkowe znamiona czynu zabronionego nie można $\mathrm{w}$ danym przepisie określić jej odmiennego zakresu. Taką też definicję należałoby przyjąc za uzasadniona w odniesieniu do procederu handlu dziećmi. Pojęcie dziecka, jako osoby od momentu poczęcia do uzyskania pełnoletności, zapewni mu bowiem pełną ochronę prawnokarną. Dla pełnej przejrzystości i wyeliminowania rozbieżności przy stosowaniu prawa karnego, także w zakresie handlu dziećmi, należałoby w tym miejscu postulować de lege ferenda wprowadzenie jednoznacznej definicji dziecka do katalogu pojęć ustawowych $\mathrm{w}$ art. 115 k.k. Wydaje się, że jedynie szeroko ujęta definicja dziecka, określająca je jako istotę ludzką od momentu poczęcia do uzyskania pełnoletności, zapewni mu właściwą opiekę państwa oraz karnoprawną ochronę. Będzie ona nadto zgodna $\mathrm{z}$ unormowaniami prawa międzynarodowego, w szczególności z Konwencją o prawach dziecka, która już w samej preambule podkreśla, że dziecko ,z uwagi na swoją niedojrzałość fizyczną oraz umysłową, wymaga szczególnej opieki i troski, w tym właściwej ochrony prawnej, zarówno przed, jak i po urodzeniu".

Moment, od którego istota ludzka uznawana jest za osobę, stanowi podstawę wyodrębnienia klasyfikacji filozoficznych koncepcji osoby, wśród których

\footnotetext{
${ }^{16}$ Dz. U. 1964, Nr 16, poz. 93 ze zm.

${ }^{17}$ Dlatego też definicję małoletniego, w związku z brakiem takowej w Kodeksie karnym, należy pojmować w odniesieniu do prawa cywilnego i rodzinnego. Osobą małoletnią w rozumieniu polskiego prawa cywilnego (art. 10 k.c.) jest osoba, która nie ukończyła 18 lat i nie uzyskała pełnoletności w związku z zawarciem małżeństwa.

${ }^{18}$ Dz. U. 2000, Nr 6, poz. 69 ze zm.

19 J. Potulski, Dziecko jako przedmiot czynu zabronionego, Wydawnictwo Uniwersytetu Gdańskiego, Gdańsk 2007, s. 39.

20 Ibidem.
} 
wyróżnia się: antropologię chrześcijańska, tzw. stanowisko neokantowskie (określane jako moralna koncepcja osoby), ontologię rozwojową oraz koncepcję paradygmatyczną ${ }^{21}$. Według antropologii chrześcijańskiej osobą jest każda istota ludzka już od pierwszego momentu jej istnienia. Godność osobowa, zgodnie z tą koncepcja, przysługuje zatem embrionowi i płodowi, niezależnie czy znajduje się on $\mathrm{w}$ łonie kobiety, czy poza nim. Inne podejście prezentuje stanowisko neokantowskie, zgodnie z którym osoba jest wyłącznie osoba „rozumna i wolna, zdolna do podjęcia odpowiedzialności wobec innych podmiotów", a zatem istota ludzka zyskuje status osoby dopiero na określonym etapie swojego rozwoju. Ontologia rozwojowa z kolei nie precyzuje definicji osoby ani nie określa momentu, w którym życie osobowe bierze swój początek. Embrion w tym wypadku nie jest traktowany w kategoriach osoby, a jedynie „,samoistnej wartości związanej z istniejącą w nim potencjalnością umożliwiającą mu stopniowe przekształcenie się w osobę". Ostatnia $\mathrm{z}$ wymienionych koncepcji, tzw. koncepcja paradygmatyczna, za kryterium osobowości przyjmuje możliwość nawiązania więzi społecznych, a osobą według niej jest człowiek od momentu jego urodzenia ${ }^{22}$. Obok klasyfikacji koncepcji filozoficznych „osoby” na podstawie kryterium momentu, od którego istota ludzka ma być uznana za osobę, wyróżnia się także filozoficzne koncepcje ,osoby” na podstawie kryterium moralnego statusu płodu ludzkiego opracowane przez W. Langa. Jak wskazuje J. Kondratiewa-Bryzik, logicznie możliwe jest powstanie 35 takich koncepcji. Ramy niniejszego opracowania nie pozwalaja jednak na ich pogłębioną analizę. Wskazać jednak należy, że według W. Langa spór o moralna podmiotowość płodu nie jest ostatecznie rozstrzygalny, gdyż wybór koncepcji osoby jest wyborem moralnym, a dokładnie - wyborem systemu wartości wpływającym na rozwiązania normatywne ${ }^{23}$.

Pozostając jednak w kręgu rozważań na temat handlu dziećmi, wskazać należy, że w art. 1 Konwencji o prawach dziecka ${ }^{24}$ „dziecko” zostało zdefiniowane jako każda istota ludzka w wieku poniżej osiemnastu lat, chyba że zgodnie z prawem odnoszącym się do dziecka uzyskała ona wcześniej pełnoletność. Wskazana konwencja wprawdzie nie precyzuje momentu, od którego życie dziecka bierze swój początek, jednakże mając na względzie ujęte w preambule zagwarantowanie dziecku właściwej ochrony prawnej ,zarówno przed, jak i po urodzeniu", należy uznać, że dziecku jeszcze nienarodzonemu przysługuje taka sama opieka i troska, w tym również ochrona prawna, jak dziecku urodzonemu. Podobne podejście przedstawia także tzw. deklaracja praw dziecka $\mathrm{ONZ}^{25}$.

Przechodząc do przedmiotu dalszych rozważań, należy podkreślić, że konsekwencją braku definicji pojęcia „dziecko” w polskim prawie karnym jest również brak szczególnych unormowań dotyczących samego pojęcia handlu

${ }^{21}$ J. Kondratiewa-Bryzik, Poczatek prawnej ochrony życia ludzkiego $w$ świetle standardów międzynarodowych, Warszawa 2009, s. 29, za: M. Safjan, Prawo wobec ingerencji w nature ludzkiej prokreacji, Warszawa 1990, s. 329 i n.

${ }^{22}$ Ibidem; zob. też cytowaną tam literaturę.

${ }^{23}$ Ibidem, s. 32; zob. też cytowaną tam literaturę.

${ }^{24}$ Konwencja o prawach dziecka, przyjęta przez Zgromadzenie Ogólne Narodów Zjednoczonych 20 listopada 1989 r., Dz. U. 2000, Nr 2, poz. 11 ze zm.

${ }^{25}$ M. Andrzejewski, Prawo rodzinne i opiekuńcze, C. H. Beck, Warszawa 2010, s. 19. 
dziećmi. Ustawodawca nie wyodrębnił go jako oddzielnego czynu zabronionego w Kodeksie karnym, co zdaje się błędem. Pojęcie „handel dziećmi” zostało włączone w zakres ogólnie ujętego handlu ludźmi i rozszerza podmiot czynu zabronionego z art. 189a $\S 1$ k.k. Zgodnie z treścią art. 189a $\S 1$ k.k. karze pozbawienia wolności na czas nie krótszy od 3 lat podlega ten, kto dopuszcza się handlu ludźmi. Przepis ten wprowadza również karalność przygotowania do popełnienia przestępstwa handlu ludźmi, która jest uzasadniona wysokim stopniem społecznej szkodliwości omawianego czynu ${ }^{26}$. Normatywne pojęcie „,handel ludźmi” ${ }^{27}$, zawarte w art. 115 § 22 k.k., określa go jako ,werbowanie, transport, dostarczanie, przekazywanie, przechowywanie lub przyjmowanie osoby $\mathrm{z}$ zastosowaniem: przemocy lub groźby bezprawnej, uprowadzenia, podstępu, wprowadzenia $\mathrm{w}$ błąd albo wyzyskania błędu lub niezdolności do należytego pojmowania przedsiębranego działania, nadużycia stosunku zależności, wykorzystania krytycznego położenia lub stanu bezradności lub udzielenia albo przyjęcia korzyści majątkowej lub osobistej albo jej obietnicy osobie sprawującej opiekę lub nadzór nad inną osobą - w celu jej wykorzystania, nawet za jej zgoda, w szczególności w prostytucji, pornografii lub innych formach seksualnego wykorzystania, w pracy lub usługach o charakterze przymusowym, w żebractwie, w niewolnictwie lub innych formach wykorzystania poniżających godność człowieka lub w celu pozyskania komórek, tkanek lub narządów wbrew przepisom ustawy".

Odnosząc się pozytywnie do umieszczenia w przepisach Kodeksu karnego definicji handlu ludźmi, należy zauważyć, że różni się ona nieco od definicji handlu ludźmi zawartej w przepisach prawa międzynarodowego, a zwłaszcza w dyrektywie 2011/36/UE z 5 kwietnia 2011 r. w sprawie zapobiegania handlowi ludźmi i zwalczania tego procederu oraz ochrony ofiar, która w art. 2 ust. 1 wskazuje, że „handlem ludźmi jest umyślne werbowanie, transport, przekazywanie, przechowywanie lub przyjmowanie osób, w tym wymiana lub przekazywanie kontroli nad tymi osobami, z zastosowaniem groźby lub przemocy bądź innych form przymusu, uprowadzenia oszustwa, podstępu, poprzez nadużycie uprawnień lub wykorzystanie sytuacji bezbronności, lub też wręczenie lub przyjęcie płatności lub korzyści dla uzyskania zgody sprawującej kontrolę nad inną osoba w celu wyzysku" ${ }^{28}$. Porównując obie wskazane powyżej definicje, trzeba zauważyć, że polski ustawodawca w art. $115 \S 22$ k.k. rozszerza przede wszystkim czynności sprawcze o dostarczanie osoby, czego nie

\footnotetext{
${ }^{26}$ Uzasadnienie rzadowego projektu ustawy o zmianie ustawy - Kodeks karny, ustawy - Przepisy wprowadzajace Kodeks karny, ustawy - Kodeks postepowania karnego oraz ustawy o Policji, druk sejmowy nr 2387.

${ }^{27}$ Definicja handlu ludźmi została wprowadzona do Kodeksu karnego dopiero ustawą z 20 maja 2010 r. o zmianie ustawy - Kodeks karny, ustawy o Policji, ustawy - Przepisy wprowadzające Kodeks karny oraz ustawy - Kodeks postępowania karnego, Dz. U. 2010, Nr 98, poz. 626. Szerzej na temat definicji handlu ludźmi w: K. Liżyńska, A. Płońska, Wspótczesne polskie prawo karne wobec handlu ludźmi, w: T. Bojarski et al., Teoretyczne i praktyczne problemy wspótczesnego prawa karnego, Lublin 2011; eaedem, Kilka refleksji nad definicja handlu ludźmi, „Przegląd Prawa i Administracji” 85, 2011; E. Zielińska, Zakaz handlu ludźmi w polskim prawie karnym, w: Handel ludźmi w Polsce. Materiaty do raportu 2009, Ministerstwo Sprawiedliwości 2009; eaedem, O potrzebie zmian kodeksu karnego w zwiazku z ratyfikacja protokołu o zapobieganiu oraz karaniu handlu ludźmi, „Studia Iuridica” 46, 2006.

${ }^{28}$ Dz. Urz. UE z 15 kwietnia 2011 r., L 101/1-11.
} 
przewiduje definicja zawarta we wspomnianej dyrektywie. Ponadto posługuje się pojęciem osoby w liczbie pojedynczej, co zdaje się usuwać wszystkie dotychczasowe kontrowersje dotyczące uznania za przestępstwo handlu ludźmi czynu polegającego na dokonaniu „transakcji” na jednej osobie ${ }^{29}$. Dyrektywa natomiast dodatkowo wskazuje na pominięte w k.k. przyjmowanie osób rozumiane jako wymiana lub przekazywanie kontroli nad tymi osobami.

Jeżeli natomiast zachowanie sprawcy dotyczy małoletniego, zgodnie z art. $115 \S 22$ k.k. stanowi ono handel ludźmi, ,,nawet gdy nie zostały użyte metody lub środki wymienione powyżej”. Sformułowanie użyte przez ustawodawcę w art. 115 § 2 k.k. in fine zdaje się niewystarczające, gdyż mówi tu o małoletnim, którego zakres pojęciowy jest węższy od pojęcia dziecka.

Mając na uwadze handel dziećmi, dostrzec należy, że ustawodawca w aktualnym stanie prawnym, gdy penalizuje we wskazany wyżej sposób zachowanie sprawcy wobec małoletniego pokrzywdzonego oraz ma na względzie jego szczególną ochronę, priorytetowe znaczenie nadaje celowi działania sprawcy, którym jest werbowanie, transportowanie, dostarczanie, przekazywanie, przechowywanie lub przyjmowanie osoby. Legislator $\mathrm{w}$ przepisie art. 189a $\S 1$ k.k. kładzie nacisk na cel działania sprawcy przy wykorzystaniu ściśle określonych metod, co czyni w sposób uzasadniony. Wskazuje, że mimo iż sprawca będzie zmierzał do celu, którym jest wykorzystanie innej osoby, nawet za jej zgoda, ale za pomocą innych aniżeli wskazane $\mathrm{w}$ definicji $\mathrm{z}$ art. 115 § 22 k.k. metod, nie wypełni znamion przestępstwa $\mathrm{z}$ art. 189a $\S 1$ k.k. Jednakże gdy podmiotem jest małoletni, największe znaczenie ma cel działania sprawcy, sprowadzający się do którejś z wymienionych form wykorzystania. Metody lub środki wymienione w definicji nie musza być użyte przez sprawcę, aby uznać, że przestępstwo handlu ludźmi zostało popełnione. Innymi słowy - nawet jeśli sprawca nie użył podstępu czy przemocy, będzie on odpowiadał za handel dziećmi. Ustawodawca rozszerzył zatem ochronę małoletniego przez ograniczenie kwalifikacji prawnej czynu wyłącznie do celu działania sprawcy, którym jest werbowanie, transportowanie, dostarczanie, przekazywanie, przechowywanie lub przyjmowanie osoby ${ }^{30}$.

W odniesieniu do handlu dziećmi ustawodawca, ograniczając czynność sprawczą art. $115 \S 22$ k.k., dał wyraz ochrony małoletniego. Jednakże zabieg ten wydaje się niewystarczający. Mając na względzie powyższe rozważania, a w szczególności kryminalistyczny obraz handlu dziećmi, podkreślić jeszcze raz należy de lege ferenda potrzebę wprowadzenia do art. 189 a k.k. kwalifikowanej postaci handlu dziećmi. Ustawodawca winien wykazać szczególnie zaostrzone podejście, gdy ofiara jest osoba wyjątkowo bezbronna i podatna na działanie sprawcy, a taką ofiara niewatpliwie jest dziecko ${ }^{31}$. Na gruncie typizacji przestępstwa handlu ludźmi w polskim prawie karnym handel bezbronnymi i niewinnymi istotami, jakimi sa dzieci, zasługuje na przydanie mu takiego

29 Takie kontrowersje budził zapis art. 253 k.k., uchylonego ustawą z 20 maja 2010 r. o zmianie ustawy - Kodeks karny, ustawy o Policji, ustawy - Przepisy wprowadzające Kodeks karny oraz ustawy - Kodeks postępowania karnego, Dz. U. 2010, Nr 98, poz. 626, który interpretowano przy braku normatywnej definicji handlu ludźmi.

30 M. Pomarańska-Bielecka, M. Wiśniewski, op. cit., s. 10-11.

${ }^{31}$ Ibidem, s. 18-19. 
statusu. Zmiany mające na celu wzmocnienie ochrony przed omawianym procederem zostały zapoczątkowane nowelizacja przepisów normujących handel ludźmi, która weszła w życie 8 września 2010 r. i miała na celu spełnienie obowiązków wynikających z ratyfikacji umów międzynarodowych. Przedmiot ochrony - dobro dziecka uzasadnia jednak podjęcie kolejnego kroku w postaci wprowadzenia kwalifikowanej postaci przestępstwa handlu ludźmi, tzn. handlu dziećmi, w brzmieniu: „kto dopuszcza się handlu dziećmi podlega karze pozbawienia wolności na czas nie krótszy od lat 5". Artykuł 189a k.k. otrzymałby zatem brzmienie: „§ 1 . Kto dopuszcza się handlu ludźmi, podlega karze pozbawienia wolności na czas nie krótszy od lat 3 . § 2 . Kto dopuszcza się handlu dziećmi podlega karze pozbawienia wolności na czas nie krótszy od lat 5. $\S 3$. Kto czyni przygotowania do popełnienia przestępstwa określonego w $§ 1$ lub $\S 2$ podlega karze pozbawienia wolności od 3 miesięcy do lat 5". Zawyżenie dolnej granicy zagrożenia karą $\mathrm{w}$ proponowanym przepisie wynika $\mathrm{z}$ wysokiego stopnia społecznej szkodliwości handlu dziećmi. Należy mieć tu na względzie poważne konsekwencje psychologiczne ponoszone przez dziecko - ofiarę handlu. Podniesienie sankcji karnej, poza zwiększeniem ochrony dziecka, wyklucza stosowanie w wypadku popełnienia przez sprawcę takiego czynu warunkowego zawieszenia wykonania kary. Zmodyfikowana w wyżej przedstawiony sposób treść art. 189a k.k. pozwoliłaby w sposób właściwy dokonać należytej subsumpcji oraz wymierzyć właściwa karę, a zagrożenie tak wysoka kara powstrzymywałoby potencjalnych sprawców przed popełnieniem czynu zabronionego, jak również zaspokajałoby społeczne poczucie sprawiedliwości oraz dawało możliwość oddziaływania resocjalizacyjnego na sprawcę czynu zabronionego.

Analizując konsekwencje handlu ludźmi, można wskazać na ich trzy płaszczyzny, do których należą nie tylko rozwój przestępczości zorganizowanej czy naruszenie podstawowych praw człowieka, lecz także głęboko destrukcyjne skutki psychiczne i fizyczne, które to szczególne piętno odciskają na dzieciach będących ofiarami handlu ${ }^{32}$. Stąd za zasadne należy uznać określenie kwalifikowanego typu handlu dziećmi za zbrodnię. Wprowadzenie proponowanej zmiany może wywołać krytyczne głosy wskazujące na nadmierną kazuistykę, jednakże zasługuje ono na aprobatę ze względu na dobro dziecka, które ma nadrzędne znaczenie, a troska o nie pośrednio wynika także ze wspomnianego art. 72 Konstytucji RP.

Nie bez znaczenia dla zasygnalizowanego problemu jest również pomoc państwa dla ofiar przestępstwa handlu dziećmi, co zostało także dostrzeżone $\mathrm{w}$ aktach prawa międzynarodowego. Podstawowym celem dyrektywy nr 2011/36/UE jest zapewnienie środków niezbędnych do fizycznej i psychospołecznej rehabilitacji dziecka, które podejmowane będą przez państwa po przeprowadzeniu indywidualnej oceny szczególnej sytuacji każdego dziecka będącego ofiara, przy jednoczesnym należytym uwzględnieniu jego opinii, potrzeb i trosk, tak aby znaleźć trwałe rozwiązania na rzecz dziecka. Szczególna ochrona dziecka będącego ofiarą handlu wyraża się również w zapewnieniu mu

${ }^{32}$ G. Vermeulen, Handel kobietami i dziećmi - perspektywa międzynarodowa, w: Z. Lasocik (red.), op. cit., s. 160 . 
podczas postępowania przygotowawczego i sądowego przedstawiciela, gdy stosownie do prawa krajowego osoby sprawujące nad nim władzę rodzicielska nie moga go reprezentować z powodu konfliktu interesów. Ponadto gdy ofiary nie dysponują wystarczającymi środkami finansowymi, dzieciom zapewniane jest niezwłocznie bezpłatne doradztwo prawne i zastępstwo prawne, w tym w celu dochodzenia odszkodowania ${ }^{33}$. Należy mieć jednak na względzie, że w praktyce liczba ujawnionych czynów jest niewielka, co wynika m.in. z braku dostępnych informacji oraz obaw ofiary.

Konkludując rozważania, należy stwierdzić, że dziecko wymaga zagwarantowania ochrony prawnej na najwyższym poziomie. Eliminacja zjawiska handlu dziećmi wymaga holistycznego podejścia, mającego na względzie identyfikację przyczyn tego procederu, zwiększenie świadomości społecznej, efektywniejsze egzekwowanie prawa na szczeblu krajowym oraz wzmocnienie współpracy międzynarodowej. Przyjęte w tym zakresie rozwiązania winny mieć zdecydowanie systemowy charakter i opierać się nie tylko na skutecznym zwalczaniu, lecz także przeciwdziałaniu temu procederowi.

Ponadto należy wskazać, że podejmowane w Polsce działania mające na celu przeciwdziałanie handlowi dziećmi i zwalczanie go zostały uznane przez ECPAT International ${ }^{34}$ za niezadowalające. Zarzucano im głównie zajmowanie się nimi w kontekście ogólnie pojętego handlu ludźmi ${ }^{35}$. Z raportów opracowanych w 2010 r. przez międzynarodową organizację ECPAT oraz Komitet Praw Dziecka ONZ wynika, że co prawda w Polsce podejmowane sa pewne działania w zakresie zwalczania zjawiska handlu ludźmi i przeciwdziałania jemu, brak jednak działań skupiających się na szczególnej ochronie dzieci, jako zidentyfikowanych lub potencjalnych ofiarach handlu ${ }^{36}$. Jest to dodatkowy argument wskazujący, że brak odrębnej penalizacji handlu dziećmi oraz samej definicji dziecka w Kodeksie karnym zasługuje na dezaprobatę.

Na szczeblu Unii Europejskiej podejmowane są różnorakie działania mające na celu zapobieganie handlowi dziećmi i jego zwalczanie. Jednakże sa one ograniczone i wydaje się, że niewystarczające ze względu na brak odpowiednich zapisów w traktatach unijnych. W praktyce oznacza to, że nie tylko problematyką praw dzieci, lecz także przeciwdziałaniem omawianemu procederu powinny się zajmować państwa członkowskie ${ }^{37}$. W ramach UE wypracowano wiążące dla państw członkowskich akty prawne, do których należą decyzja ramowa z 19 lipca 2002 r. w sprawie zwalczania handlu ludźmi ${ }^{38}$, decyzja ramowa z 22 grudnia 2003 r. dotycząca zwalczania

${ }^{33}$ K. Liżyńska, A. Płońska, Wspótczesne polskie prawo karne..., s. 281.

${ }^{34}$ End Child Prostitution Child Pornography \& Trafficking of Children for Sexual Purposes (ECPAT) jest międzynarodową siecią organizacji pozarządowych podejmujących działania w celu wyeliminowania problemu dziecięcej prostytucji, dziecięcej pornografii i handlu dziećmi dla celów komercyjnego wykorzystywania seksualnego. Polska Koalicja przeciwko Komercyjnemu Wykorzystywaniu Seksualnemu Dzieci, koordynowana przez Fundację Dzieci Niczyje, jest w niej stowarzyszona od 2009 r.

${ }^{35}$ Raport Fundacji Dzieci Niczyje, Problem handlu dziećmi w Polsce - opinie $i$ doświadczenia profesjonalistów, s. 3; wersja elektroniczna: www.dzieci.ofiaryhandlu.fdn.pl (dostęp: 10.09.2012).

36 Ibidem.

${ }^{37}$ M. Koss, Międzynarodowe instrumenty zwalczania handlu dziećmi, w: Z. Lasocik, M. Koss, Ł. Wieczorek (red.), op. cit., s. 69 i n.

${ }^{38}$ Dz. Urz. L 203 z 1 sierpnia 2002 r. 
seksualnego wykorzystywania dzieci i pornografii dziecięcej ${ }^{39}$, decyzja Rady z 29 maja 2000 r. w sprawie zwalczania pornografii dziecięcej w Internecie ${ }^{40}$. Należy także wskazać istotne $\mathrm{z}$ punktu widzenia przeciwdziałania handlowi dziećmi komunikaty, deklaracje i rezolucje, chociaż nie mają one wiążącego charakteru, takie jak: komunikat Komisji z 4 lipca 2006 r. w kierunku strategii UE na rzecz praw dziecka ${ }^{41}$, Komunikat Komisji dla Parlamentu Europejskiego i Rady: Zwalczanie handlu ludźmi - zintegrowane podejście oraz wnioski dotyczące planu działania ${ }^{42}$, czy też Plan $\mathrm{UE}^{43}$ dotyczący najlepszych praktyk, standardów i procedur zwalczania handlu ludźmi i jemu zapobiegania ${ }^{44}$.

Handel dziećmi niewątpliwie jest jednym z najpoważniejszych przejawów łamania praw człowieka. Dlatego też zwalczanie tego procederu znajduje miejsce wśród wielu międzynarodowych instrumentów. Należy wskazać tu m.in. ONZ-owskie akty prawa międzynarodowego, takie jak: Konwencja NZ przeciwko międzynarodowej przestępczości zorganizowanej, Protokół o zapobieganiu, zwalczaniu oraz karaniu za handel ludźmi, w szczególności kobietami i dziećmi (tzw. protokół z Palermo), Konwencja o prawach dziecka, Protokół fakultatywny do Konwencji o prawach dziecka w sprawie handlu dziećmi, dziecięcej prostytucji i dziecięcej pornografii czy też Protokół fakultatywny do Konwencji o prawach dziecka $\mathrm{w}$ sprawie angażowania dzieci $\mathrm{w}$ konflikty zbrojne. Rzeczpospolita Polska ratyfikowała Konwencję o prawach dziecka ${ }^{45}$ 30 września 1991 r., w 2004 r. został ratyfikowany przez Rzeczpospolita Polska Protokół dodatkowy do Konwencji o prawach dziecka w sprawie handlu dziećmi, dziecięcej prostytucji i dziecięcej pornografii ${ }^{46}$, a 26 września 2003 r. Rzeczpospolita Polska ratyfikowała kolejny akt prawa międzynarodowego odnoszący się m.in. także do dzieci - Protokół o zapobieganiu, zwalczaniu oraz karaniu za handel ludźmi, w szczególności kobietami i dziećmi, przyjęty przez Zgromadzenie Ogólne Narodów Zjednoczonych 15 listopada $2000 \mathrm{r.}^{47}$, uzupełniający Konwencję Narodów Zjednoczonych przeciwko międzynarodowej przestępczości zorganizowanej ${ }^{48}$. Nie bez znaczenia w świetle prowadzonych rozważań pozostaje Konwencja o ochronie dzieci i współpracy w dziedzinie przysposobienia międzynarodowego, sporządzona w Hadze 29 maja 1993 r. ${ }^{49}$ Wymienione umowy odnoszą się do ochrony dziecka pokrzywdzonego przestępstwem i wraz z ratyfikacja przez Polskę stały się częścią krajowego porządku prawnego. Jednym $\mathrm{z}$ aktów prawa międzynarodowego chroniącego dzieci przed ich sprzedażą jest protokół z Palermo, uzupełniający Konwencję Narodów Zjednoczonych przeciwko międzynarodowej przestępczości zorganizo-

${ }^{39}$ Dz. Urz. L 13 z 20 stycznia 2004 r.

${ }^{40}$ Dz. Urz. L 138 z 9 czerwca 2000 r.

${ }^{41}$ COM (2006) 367, wersja ostateczna - niepublikowany w „Dzienniku Urzędowym”.

${ }^{42}$ COM (2005) 514, ,,Dziennik Urzędowy” C/2006/49/23.

${ }^{43}$ Dz. Urz. C 311 z 9 grudnia 2005 r.

${ }^{44}$ M. Koss, op. cit., s. 72 i n.

${ }^{45}$ Dz. U. 1991, Nr 120, poz. 526.

${ }^{46}$ Dz. U. 2004, Nr 238, poz. 2389 (dalej jako: Protokół do Konwencji o prawach dziecka).

${ }^{47}$ Dz. U. 2005, Nr 18, poz. 160 (dalej jako: protokół z Palermo).

${ }^{48} \mathrm{Dz}$. U. 2005, Nr 18, poz. 158, Konwencja przyjęta przez Zgromadzenie Ogólne Narodów Zjednoczonych 15 listopada $2000 \mathrm{r}$.

${ }^{49}$ Dz. U. 2000, Nr 39, poz. 448 ze sprost. 
wanej. Już w preambule tego aktu czytamy, że „Skuteczne działania mające na celu zapobieganie i zwalczanie handlu ludźmi, w szczególności kobietami i dziećmi, wymagaja podjęcia wszechstronnych wysiłków międzynarodowych w krajach pochodzenia, tranzytu i przeznaczenia, które obejmowałyby działania zapobiegające takiemu handlowi, mające na celu karanie sprawców oraz ochronę ofiar takiego handlu, także poprzez ochronę uznawanych na arenie międzynarodowej ich praw".

Zgodnie z Konwencją Międzynarodowej Organizacji Pracy nr $182^{50}$ wyeliminowanie zjawiska handlu dziećmi wymaga natychmiastowego i szerokiego działania, w tym zapewnienia bezpłatnego kształcenia podstawowego i odsunięcia dzieci od każdej wskazanej w ww. Konwencji pracy oraz zapewnienia im rehabilitacji i reintegracji społecznej, przy jednoczesnym zajmowaniu się potrzebami ich rodzin. Zgodnie $\mathrm{z}$ art. 3 wspomnianej Konwencji przez pojęcie „,najgorsze formy pracy dzieci” rozumiane są: wszystkie formy niewolnictwa lub praktyk podobnych do niewolnictwa, takich jak: sprzedaż i handel dziećmi, niewolnictwo za długi i pańszczyzna lub praca przymusowa albo obowiązkowa, $\mathrm{w}$ tym przymusowe lub obowiazkowe rekrutowanie dzieci do udziału w konflikcie zbrojnym; wykorzystanie, angażowanie dziecka do prostytucji (lub jej proponowanie), produkcji pornografii lub przedstawień pornograficznych; wykorzystywanie, angażowanie dziecka do nielegalnej działalności (lub jej proponowanie), w szczególności do produkcji i handlu narkotykami, jak to określają stosowne traktaty międzynarodowe, oraz praca, która ze względu na swój charakter lub okoliczności prowadzenia może zagrażać zdrowiu, bezpieczeństwu lub moralności dzieci ${ }^{51}$.

Dążenia do wzmocnienia postanowień Konwencji o prawach dziecka w obliczu nasilającego się procederu międzynarodowego obrotu dziećmi 25 maja 2000 r. doprowadziły do przyjęcia w Nowym Jorku Protokołu fakultatywnego do Konwencji o prawach dziecka w sprawie handlu dziećmi, dziecięcej prostytucji i dziecięcej pornografii ${ }^{52}$. Protokół w art. 2 definiuje handel dziećmi jako ,jakiekolwiek działanie lub transakcję, w drodze której dziecko przekazywane jest przez jakakkolwiek osobę lub grupę osób innej osobie lub grupie za wynagrodzeniem lub jakąkolwiek inną rekompensatą". Protokół ten nie zawęża procederu handlu dziećmi, zatem i handlu ludźmi do działań w ramach przestępczości zorganizowanej bądź o charakterze międzynarodowym (art. 3 pkt 1). Powyższy protokół w kwestii handlu dziećmi przewiduje pełną kryminalizację oferowania, dostarczenia lub przyjęcia dziecka $\mathrm{w}$ jakikolwiek sposób w celu jego seksualnego wykorzystania, angażowania do pracy przymusowej czy też przekazywania jego organów dla zysku oraz nakłaniania w niewłaściwy sposób, jako pośrednik, do udzielenia zgody na adopcję dziecka z naruszeniem odpowiednich międzynarodowych instrumentów prawnych

\footnotetext{
${ }^{50}$ Konwencja nr 182 Międzynarodowej Organizacji Pracy dotycząca zakazu i natychmiastowych działań na rzecz eliminowania najgorszych form pracy dzieci, przyjęta w Genewie 17 czerwca 1999 r. Dz. U. 2004, Nr 139, poz. 1474.

${ }^{51}$ K. Liżyńska, A. Płońska, Wspótczesne polskie prawo karne..., s. 281.

${ }^{52}$ Ustawa z 10 września 2004 r. o ratyfikacji Protokołu fakultatywnego do Konwencji o prawach dziecka w sprawie handlu dziećmi, dziecięcej prostytucji i dziecięcej pornografii, przyjętego w Nowym Jorku 25 maja 2000 r., Dz. U. 2004, Nr 238, poz. 2389.
} 
dotyczących adopcji, bez względu na to, czy przestępstwa takie zostały popełnione w kraju czy za granica, oraz bez względu na to, czy zostały popełnione w sposób zorganizowany czy też przez pojedyncze osoby. Jest to najbardziej restrykcyjny przepis prawa międzynarodowego odnoszący się do handlu dziećmi ${ }^{53}$. Porównując przyjętą na gruncie Kodeksu karnego definicję handlu ludźmi ze stosowanymi w tym zakresie aktów prawa międzynarodowego, należy zaznaczyć, że wypełnia ona zobowiązanie międzynarodowe, a skoro dodatkowo odnosi się do handlu narządami ludzkimi, stanowi niejako kompilację innych definicji. O ile jednak przepisy prawa międzynarodowego definiują pojęcie dziecka, o tyle w polskich unormowaniach w celu wyjaśnienia pojęcia dziecka konieczne jest odniesienie się do innych przepisów ${ }^{54}$.

Handel dziećmi stanowi problem o charakterze międzynarodowym, dlatego działania mające na celu zwalczanie tego procederu i przeciwdziałanie mu powinny mieć charakter globalny, a rozwiązania prawne i polityka społeczna powinny odpowiednio chronić dzieci przed wszelkimi formami wyzyskiwania ${ }^{55}$. Zatem zasadne wydaje się zwiększenie prawnokarnej ochrony dzieci przed wspomnianym procederem przez wprowadzenie do Kodeksu karnego zarówno definicji dziecka dokładnie wskazującej moment, od którego istota ludzka jest dzieckiem, jak i definicji przestępstwa handlu dziećmi. Uzasadnioną w kontekście procederu handlu dziećmi definicją jest najszersza definicja, określająca dziecko jako istotę ludzką od momentu poczęcia do uzyskania pełnoletności. Wydaje się, że jedynie taka definicja dziecka zapewni mu właściwą opiekę państwa i będzie zgodna $\mathrm{z}$ unormowaniami prawa międzynarodowego. Natomiast proponowane wprowadzenie kwalifikowanego typu przestępstwa handlu ludźmi w postaci art. 189a $§ 2 \mathrm{k} . \mathrm{k}$., przewidującego karę pozbawienia wolności na czas nie krótszy niż 5 lat za handel dziećmi zagwarantowałoby najwyższy poziom karnoprawnej ochrony dzieci.

dr Katarzyna Liżyńska

Uniwersytet Wroctawski

dr Anna Plońska

Uniwersytet Wroctawski

${ }^{53}$ M. Pomarańska-Bielecka, M. Wiśniewski, op. cit., s. 25.

54 Ibidem, s. 18.

${ }^{55}$ L. Lööf, Dzieci i mtodzież - ofiary handlu. Dziatania regionalne na rzecz zapewnienia prawa do ochrony, opieki i rehabilitacji, „Dziecko Krzywdzone” 2005, nr 4, s. 21. 


\title{
ANALYSIS OF THE REGULATIONS ON CHILD TRAFFICKING UNDER CURRENT POLISH CRIMINAL LAW
}

\begin{abstract}
Summary
The postulate proposed in this paper is that State authorities should consider criminal law protection of children as a priority. Protection of a child is also guaranteed by relevant provisions of the Constitution of the Republic of Poland. However, an analysis of the binding criminal law regulations, particularly in the scope of children trafficking, shows that the State fails to provide for their adequate protection, despite the fact that pursuant to the Law of 20 May 2010, article 189a providing for penalisation of human trafficking has been recently added to the Criminal Code (Journal of Laws No. 98, item 626) replacing former article 253. Pursuant to the same Law, a statutory definition of human trafficking has also been introduced. A question asked in the paper is to what extent these amendments to the Criminal Code contribute to the antitrafficking protection of children. It is proposed de lege ferenda that a statutory definition of a child should be formulated and adopted. This would eliminate the current interpretation difficulties. A recommendation to introduce another type of qualified offence under article 189a of the Criminal Code is also made with a view to toughen the criminal liability of perpetrators who commit the offence of child trafficking. The authoresses believe that these changes will ensure a much higher level of child protection.
\end{abstract}


Copyright of Journal of Law, Economics and Sociology is the property of Faculty of Law and Administration of Adam Mickiewicz University in Poznan and its content may not be copied or emailed to multiple sites or posted to a listserv without the copyright holder's express written permission. However, users may print, download, or email articles for individual use.

Właścicielem praw autorskich do „Ruchu Prawniczego, Ekonomicznego i Socjologicznego” jest Wydział Prawa i Administracji Uniwersytetu im. Adama Mickiewicza w Poznaniu. Zawartość czasopisma nie może być kopiowana, przesyłana do innych stron internetowych bądź zamieszczana na blogach bez pisemnej zgody wydawcy. Niemniej artykuły można drukować, kopiować lub przesyłać w formie elektronicznej na własny użytek. 